\title{
Constructing \\ the Arcto-Pacific
}

\section{New Challenges and Opportunities}

\author{
Alexey V. Kupriyanov
}

\author{
Alexey V. Kupriyanov \\ Russian Academy of Sciences, Moscow, Russia. \\ Senior Researcher \\ ORCID: 0000-0002-9041-6514 \\ 23 Profsoyuznaya Str., Moscow 117997, Russia \\ DOI: $10.31278 / 1810-6374-2020-18-4-178-191$
}

Primakov National Research Institute of World Economy and International Relations,

\begin{abstract}
This article is devoted to considering and providing grounds for a promising geopolitical construct of the future-the Arcto-Pacific-which may be destined to complement the idea of Greater Eurasia. The author believes that favorable conditions are emerging for tapping the economic potential of the Arctic seas. Global warming allows for using northern routes to an ever greater extent, while booming Asian economies, and China in the first place, are a reason for redirecting transit flows through the Arctic. Until just recently, the Northern Sea Route's development was relatively slow, as the alternative one through the Suez Canal was more reliable, by and large, in terms of costs and delivery time. The beginning of a Cold War between the United States and China serves as an incentive to opting for a different cargo traffic artery linking China and Europe. In contrast to the southern route, shipping through the Arctic is safer and ever more predictable with every passing year. In combination with the import of natural resources from the Arctic, the possibility of northern transit is becoming a major factor in another Cold War. In a situation like this Russia will have to look out for
\end{abstract}


new partners and new diplomatic solutions in order to retain sovereignty over the Arctic seas.

Keywords: Arcto-Pacific, Arctic Ocean, China, Russia, Northern Sea Route, Arctic, Japan, Korea.

Tn his work entitled "Critical Geopolitics: The Politics of Writing Global Space" Gerard Toal wrote: "Geography is about power.

Although often assumed to be innocent, the geography of the world is not a product of nature but a product of histories of struggle between competing authorities over the power to organize, occupy, and administer space."

Together with his friends and associates John Agnew, Derek Gregory and Klaus Dodds, Toal set the task of deconstructing geopolitics as a trend in the theory of international relations. By itself, geopolitics (as Toal postulated) was a phenomenon of the late 19th century and early 20th century. It was a time when the European powers and the United States, once they had been through with the division of the world, got down to its redivision. Before that geography as a science had been the colonizers' handy tool for dictating to the conquered people the ways of organizing space that were beneficial to the Europeans. Then it became a weapon the great powers employed against each other.

This weapon is still in use: as before, countries devise and use geopolitical constructs to their own benefit. The Indo-Pacific (notorious in certain respects) is the latest construct of this sort: although the term dates back to the middle of the 19th century, it was in the first half of the 20th century that Karl Haushofer lent it a geopolitical dimension. In January 2007, India's Naval officer and analyst Gurpreet S. Khurana recovered it from oblivion. A year later Japanese Prime Minister Shinzo Abe pronounced it aloud. And it was four years after that that the United States at last turned an attentive eye to it. The Americans thought they might use the term 'Indo-Pacific' instead of the previous U.S. construct-the Asia-Pacific Region-which took shape back in the 
1960s to meet an initially unfriendly response from the region's political actors. No geographic changes have followed-the rivers still flow where they should, the islands have not turned into continents, and straits have remained straits, but the economic and political situation has changed drastically. The ASEAN countries are no longer prepared to play the role of a barrier against China. It is India that Washington now sees as a citadel against China in the south.

The example of the Indo-Pacific (Indo-Pacific Region, IPR) gives us a glimpse of how flexible and uncertain geopolitical concepts can be. These days at least five concepts are easily identifiable, each of them different from the others geographically. At the same time, some match each other well enough (for instance, the Indian and Indonesian ones, which recognize the central role of ASEAN). In general, the IndoPacific, the way the United States interprets it, is geared to containing China, while the Asian countries see its mission in breathing a new life into trading and cultural cooperation in the Indian Ocean and the western part of the Pacific Ocean along the merchant route from China to Europe and in maintaining control of this route. While the United States sees the IPR's basis in the Quadrilateral Security Dialogue (QSD, or Quad), Asia understands it as inclusive economic and cultural cooperation among all countries of the region. It is not accidental that India and the Southeast Asian countries are so much interested in Moscow's stance, because Russia has vast natural resources, a powerful Navy, and access to the Pacific.

For now, Russia is rather skeptical about the idea of the Indo-Pacific, for it sees no difference between its Asian and U.S. interpretations. Russia's Pacific Fleet is relatively small. It has no bases in the Indian Ocean and, respectively, no opportunities to project power to that region. Russia is in no mood of getting involved in conflicts in the Western Pacific. Moscow has its own alternative project-Greater Eurasia, stretching across the mainland from Vladivostok to Lisbon. The problem is this project is purely continental and of little interest to India and countries in Southeast and, to a certain extent, East Asia, whose main transport routes lie cross the sea. There is no reason for them to give up merchant shipping, which, as before, is the cheapest 
and very convenient. Insular and peninsular states, separated from the continental mainland by straits or mountain ridges, remain Greater Eurasia's neglected stepchildren.

Geopolitical constructs are social phenomena. Their emergence is possible only under certain geographic, political and economic conditions, the Indo-Pacific being a classical example of how such a construct is created. Khurana proceeded from three assumptions: firstly, China's rise required India to come up with a new geopolitical construct capable of filling the conceptual vacuum that occurred in India's foreign policy after the end of the Cold War; secondly, the Indian economy showed an annual growth rate of $9 \%$, and, consequently, was capable of providing sufficient material backing for this construct. Lastly, the geographic conditions in the broadest sense considerably facilitated its materialization. Moreover, the demand for a new ideological and political concept was ripening inside India's elites, pretty certain that India would soon be able to achieve its goal-recognition as a great power.

Have the objective factors that would create a similar construct in accordance with Russia's interests taken shape already? The way we see it, yes, although they are less obvious and differ from those observed in India's case. Amid a "Cool War" between China and the United States, which is unmistakably evolving into a Cold War, it is essential for Russia to build its own strategy and create its own construct that would best suit its own national interests. Russia's economic growth rates are behind India's economic boom of twelve years ago, but the weakness of the domestic economic base is a common problem for all of Russia's foreign policy initiatives. This does not mean that Russia should give up attempts of putting forward any such initiatives in principle, but it is beyond doubt that they should be proportionate to the economic capabilities.

In the meantime, there have surfaced some objective factors that allow for shaping a new geopolitical construct, which for convenience can be called an Arcto-Pacific Region (APR, Arcto-Pacific). There are three such main factors: the global warming, which with every passing year facilitates shipping in the Arctic; booming Pacific economies and the drift of the world economy's center to Asia; and the beginning 
of a prolonged standoff between the United States and China. A combination of these factors creates favorable conditions for turning the Arctic into a space of transit and production of resources. This process will be possible, though, only on condition of financial and economic involvement of countries situated in the northern and central parts of the Pacific Ocean. The Arctic as a zone of development and the Pacific as its driving force may well bring into being an Arcto-Pacific, which requires formalization as a concept. This concept possesses certain geographic, economic and cultural features that distinguish it from other geopolitical entities.

Arctic geopolitics is discussed in many books and essays: it was in the focus of both foreign authors (N. Wegge, L. Heininen, R. McGee, H. Peimani, P. Steinberg, and J. Tasch), and Russian researchers (N.Yu. Zamyatina, A.N. Pilyasov, N.K. Kharlampieva, and M.L. Lagutina). The list can be continued. However, as far as we know, none of them attempted to create a geopolitical construct that would take into account the long-term economic and political processes in the Asian countries and at the same time be relevant in the context of another Cold War.

\section{STRANGE HISTORY OF THE ARCTO-PACIFIC}

Most other geopolitical constructs rest upon historical, cultural, economic, and political ties. In building the Arcto-Pacific, any of these will be hardly available. Naturally, the region has its own past, but historically it is a land populated by those whom anthropologist Eric Wolf described as "people without history." For many centuries, the region's ethnic groups remained on the outskirts of the Western world. They have not created anything like the advanced civilization of the thalassocratic Tongan Empire or ancient empires of Africa or Mesoamerica: in the rigorous climates all resources were spent on survival. Economic activity was confined to hunting, gathering and reindeer breeding, while the highest forms of socio-political organizations that emerged there were tribes, clans and chiefdoms.

Outsiders from warmer lands were frequent intruders into this rigorous world-first and foremost the Russian Pomors, who traded 
with local tribes. In the 16th-17th centuries British and Dutch seafarers repeatedly ventured out along this northwestern route that would let them steer clear of Portuguese squadrons on the way to China and India. The Arcto-Pacific might have taken shape back in those days. Quite possibly just an extra couple of centuries were needed for this. Some scientists say, though, that as far as we know the Arctic ice cap has never melted away entirely in all of history. Consequently, in contrast to other maritime spaces, historically the Arctic Ocean not so much connected coastal inhabitants as divided them. During the periods of strong warming the ice shrank, but the Age of Discovery occurred during what is sometimes referred to as the Little Ice Age-a period of cooling that occurred in the 16th-19th centuries. The Arctic routes remained blocked.

The 19th century saw a resurgence of interest towards the Arctic with the beginning of gradual warming and a powerful boom in science and engineering. A real breakthrough was achieved during the inter-war period. For Soviet Russia, the Arctic was a new frontier, a space for geographic accomplishments and a source of immense riches that were to be put to the service of humanity. The Arctic's systematic development continued in the postwar years. The Canadians were exploring the Arctic, too. They built a network of weather watching stations and conducted geological exploration.

At a certain point it might seem that the collapse of the Soviet Union put an end to the Arctic Dream. Cities and communities that had been built at the cost of tremendous resources and efforts were being abandoned and falling into neglect. Unique construction and resource production technologies were forgotten and the Arctic's status as a territory of the future was quickly turning into a ghost of the past: a new Russia had neither interest in its development nor resources for it. Both re-emerged at the beginning of the 21 st century. Russia began to return to the Arctic and climatic and geopolitical conditions quite unexpectedly gave it a new chance.

\section{CLIMATE}

Global warming is an established fact, if climate scientists are to be believed; likewise, it is nakedly clear that this process began a while ago 
and when it will end is anyone's guess. The warming is most noticeable in the Arctic: the sea ice is shrinking in area much faster than any of the previous computer models suggested. Ice melting rates set one record after another, extremely cold periods are rare and do not last long, and the ice maximum decline rates have been growing. According to some estimates, by 2100 (according to some scientists, by 2050) the Arctic Ocean will be totally free from ice during summertime.

This warming will entail both negative and positive effects. It is expected that methane gas emissions will increase with the melting of the permafrost; problems will emerge with infrastructures, such as pipelines and buildings in permafrost areas. On the other hand, ice melting will open Arctic routes to shipping. In 2007, the Northwest Passage opened to shipping completely for the first time in the history of observation, and 2020 was a record year for the Northern Sea Route: it was completely clear of ice already in the middle of July (Zoledziowski, 2020). Naturally, this does not mean that the Northern Sea Route or the Northwest Passage will turn into an analogue of the Suez Canal overnight-contrary to some very optimistic forecasts. But the period of navigation will become longer and the requirements for equipping ships and using icebreakers will be less stringent. Consequently, the conditions of shipping along the Northern Sea Route will become much better, thus making it far more lucrative. For the time being this is true only of the summer period, but with the current warming rates as they are, it is quite possible that the route will be navigable all year round at some future date.

Some scientists warn, though, that climate change is unpredictable and very soon the global warming may slow down. Even if it continues at the current pace, it should not be ruled out that temperature changes will bring about unpredictable effects as far as the movement of ice floes is concerned, and the ice situation along the Northern Sea Route may even get worse. To keep the Northern Sea Route operational all year round, Russia is pushing ahead with its program for building icebreakers and ice class ships.

But this route's development and offshore extraction of mineral resources will be possible only if there are enough ship-owners ready 
to send their vessels across the Arctic and consumers prepared to purchase Arctic oil and gas.

\section{THE ASIAN AGE}

The 20th century is destined to become the Pacific Age, just like the 19th century was destined to be the Atlantic Age, one of the founding fathers of Japanese geopolitics, Inagaki Manjiro, wrote in the early 1890s. Both the Americans and the Australians would eagerly subscribe to this. Either country saw itself, and nobody else, as the engine of the Pacific Age, though. Both were wrong: the Pacific Age, or Asian Age as it is sometimes called, set in one century later, and its main driving force is China.

In 2017, according to the World Bank, three countries in Northeast Asia-China, Japan, and South Korea-accounted for more than 23\% of the world GDP, and Asia, for 35.79\%-more than any other part of the world, and in 2019, 24\% and $36.77 \%$, respectively. And this share keeps increasing: Asia's economy has been growing faster than the others, with India and Northeast Asian countries being the main boosters. In the breakdown of their foreign trade (China's in the first place) Europe holds a prominent place: in 2019 Europe's commodity trade with China was estimated at $\$ 560$ billion (EC, 2020a), with Japan, at $\$ 124$ billion (EC, 2020b) and with South Korea, at $\$ 90.7$ billion (EC, 2020c). The bulk of this trade is via the trade route lying across the Southern Pacific and the Indian Ocean, the Suez Canal and the Mediterranean. One may even chart a virtual line from the West to the East, dividing the East Asian countries into two groups. China, South Korea, and Japan lie north of this line. Cargo shipping to Europe along the northern route for them, all other factors being equal, will be faster and less costly. For each of these countries the route would be a third shorter and ten days faster.

The other related factors are equal only in theory: whereas ships keep moving along the southern route with clockwork accuracy and precision, the northern one is abundant with surprises, which moves this abstract dividing line farther north. On the other hand, in case of an international armed conflict at any point on the route, 
first and foremost in the Strait of Malacca or the Suez Canal, the line may quickly move to the south. Obviously, no farther than the Malay Barrier: for the countries of the Indian Ocean basin shipping cargoes even around the Cape of Good Hope will be cheaper, but for countries in the northwestern part of the Pacific the Arctic routes constitute a real alternative from June to October.

Similarly, Northeast Asian countries are interested in the Arctic as a storehouse of resources. Persian Gulf oil is cheaper, but relying entirely on this energy source amid world instability would be quite risky-it is not accidental that all major consumers who lack oil and gas resources of their own are keen to diversify the list of providers.

In 2017, at an official opening of the One Belt One Road forum Russian President Vladimir Putin called for making the Northern Sea Route a "global, competitive transport artery." However, soaring tensions between Russia and the West forced some changes: the European countries one by one began to express doubts over the feasibility of the Northern Sea Route for ecological reasons. As a result, Russia's strategy in the Arctic was totally refocused on oil and gas production, which pollutes the environment to a no smaller extent. However, the confrontation between the U.S. and China may change the situation abruptly.

\section{THE COLD WAR}

The sudden worsening of Chinese-U.S. relations brought about a standoff that many analysts have already likened to another Cold War. This confrontation began in a situation extremely unfavorable for Beijing: the strength of China's economy depends heavily on overseas trade, but China lacks a sea-going naval fleet capable of challenging the U.S. one even in the Pacific, let alone on the world scale. At this point, the strength of China's Navy is weaker than that of the U.S., and to gain sufficient freedom of maneuver it has to negotiate at least two island chains. To put it in a nutshell, China's trade depends entirely on the United States' good will and its preparedness to observe international law even in the context of a clash for world hegemony.

As has been stated above, the southern route is the most important one to China, and most vulnerable as well. It lies through the Strait 
of Malacca close to U.S. naval and air bases in Singapore; across the Indian Ocean - the unrivaled domain of U.S. and Indian fleets; and through the Mediterranean, where the United States' 6th Fleet is on duty. Traffic along this route can be disrupted at any of these points.

The Northern Sea Route is far less vulnerable to U.S. intervention. It stretches along Russia's Arctic shores and in Russia's territorial waters, firmly protected by Russia's military bases, coastal missile system, aviation, and ice-class patrol ships, which began to be built on a large scale lately. Currently, any disruption of traffic along the southern route would be critical to China; if a northern alternative is available, the situation will turn for the worse, too, but China will continue to get oil and gas from the Arctic instead of the Persian Gulf and maintain trade with Europe. Of course, the Arctic transit and natural resource production will be far more costly, but at a time when security and the outcome of the clash for hegemony are at stake, the costs do not matter.

\section{CHALLENGES AND THREATS}

The combination of these factors testifies to the emergence of objective conditions in which the Arcto-Pacific can be conceptualized. Its real content is to be provided by East Asian countries, first and foremost China, for which all three factors are of importance, and to a smaller extent, Japan and South Korea, for which only two factors are significant. Tokyo and Seoul may also see extra benefits in the Northwest Passage. Should it materialize, cargoes will be delivered to the United States' East Coast and Europe at far lower costs than along the southern route. This means that in the foreseeable future the Pacific countries may take special interest in the Arctic transit and reserves. In the current situation it makes sense to hurry to conceptualize the Arcto-Pacific before other countries do it.

The creation of an Arcto-Pacific Region will yield not only benefits but will also breed risks and challenges for the economy, politics and security.

The economy. Global warming is quite a problem for the existing Arctic infrastructures. As the permafrost melts away, gas and oil pipelines 
will be deformed and buildings standing upon piles will sag and sink. According to some estimates, infrastructure losses may soar to $\$ 250$ billion by 2050 (RIA, 2020). This requires a fundamental revision of the approach to building cities and infrastructures, the introduction of new technologies and, possibly, even restrictions on pipeline traffic and greater emphasis on delivery by tankers. Alongside this the demand for household gas is expected to go down; this drop in demand may partially be compensated for as coal-fueled electric power plants will give way to gas-fueled ones and liquefied natural gas will be increasingly used as engine fuel.

On the other hand, the warming of Arctic seas opens up wide opportunities for the development of the blue economy (Brzozowski, 2019) and conversion of maritime communities into hubs for the development of underwater and ground territories. The key problem is that Russia's resources are hardly enough to cope with fast-tracked modernization of this type: in any case, it will need assistance from other countries, such as investment and technologies. The main task is to ensure the countries that agree to provide the required resources should not interpret this process as a hint at changing the status of Arctic territories.

Politics. The Arcto-Pacific, as it was mentioned above, to a certain extent, is a stark contrast to the absolute majority of other geopolitical constructs, in which the sea was historically a connecting space for cultural, economic, and political exchanges and was perceived as a space that could not be effectively put under control. The Arcto-Pacific Region is emerging at a time when such control is quite possible, and the historical basis for recognizing it as mare liberum is absent; in other words, in fact, it is mare clausum, where the Arctic countries mutually recognize each other's interests and can dispute delimitation lines, but at the same time remain unanimous in their wish to keep the region closed to outsiders, who have been ever more active in their attempts to penetrate and gain a firmer foothold in the Arctic. The country that is most persistent in this respect is China, which lays claim to the status of a "near-Arctic state" (Gudev, 2018a; Gudev, 2018b). 
Consequently, Russia, which is capable of effectively and comprehensively developing the Arctic only with the help of these external actors, is faced with the task of formulating an inclusive Arcto-Pacific concept that would guarantee the observance of Russian political interests. The first step along these lines was taken with the adoption of the Basic Principles of Russia's State Policy in the Arctic till 2025, which by virtue of the document's nature draws only a very general outline of the Arctic policies for the next fifteen years.

Security. Security is the acutest issue of all. On the one hand, the functioning of the Arcto-Pacific is possible if there is no direct confrontation in the region: the Bering Strait is the most vulnerable zone, easily blocked by Russia or the United States. Fortunately, the risk of war between the two nuclear powers is tiny.

On the other hand, Russia is interested in retaining control of the Northern Sea Route and ensuring controlled merchant shipping in accordance with the established Navigation Rules, some of which draw objections from other countries. Also, the question arises how exactly Russia will guarantee this control in a situation where non-Arctic countries will be trying to use their own icebreakers for escorting ships, and the countries that press for the absolute freedom of shipping in Russia's Arctic seas will try to enforce the Freedom of Navigation Operations-FONOPs. Moscow will have to exert great efforts to explain to all countries concerned that their attempts to violate Russia's sovereignty will entail colossal strategic losses. Above all this concerns China, which runs the risk of losing a safe shipping route across the Arctic seas and suffering a defeat in a Cold War with the United States.

\section{MARITIME COMPONENT OF GREATER EURASIA}

In conclusion it is worth noting that a combination of a number of strategic factors is creating a situation where Asian countries come to the fore as the main driving force of Arctic development. For Russia this opens a window of opportunities, because the shortest way to Europe lies through its territorial waters and the adjoining areas, as well as the exclusive economic zone. Moscow will have to maintain its 
unconditional sovereignty over this route while drawing investment from other countries, interested in economic presence in the Arctic (India, South Korea, Japan, Australia, and France). This is a daunting task and Russia will have to display great skill of concluding pacts with some actors against others on certain issues.

The Arctic Council must become a platform where such deals can be clinched: after all, the creation of the Arcto-Pacific will one way or another concern all Arctic countries and territories, which are equally interested to ensure that each newcomer to the region should contribute to the sustainable development of territories and maritime areas and the preservation of biodiversity, and not cause their devastation as a result of predatory exploitation. Special attention will have to be paid to the preservation and development of cultures and environments of the Arctic's indigenous ethnic groups, for whom the maritime space that once separated them may be turned into a space of opportunities.

Conceptualization of the Arcto-Pacific will at last help formulate Russia's vision of the Indo-Pacific Region. It totally rejects the U.S. approach to the IPR, which envisages the containment of China, but matches well the Asian approaches, which rest upon the idea of inclusiveness and central role of ASEAN. In fact, the Arcto-Pacific and the Indo-Pacific, the way it is understood in Asia, complement each other well enough, with Russia's Far East being the point of synergy. Cooperation by countries within the framework of pairing the two concepts will be possible only if there is the recognition of priority of Russia's political and security interests in the Russian Arctic, India's interests in the Indian Ocean, and ASEAN countries' and China's interests in the Western Pacific, alongside the attraction of investment and creation of incentives to third counties' economic activity in the respective regions. Alongside this, for Russia the Arcto-Pacific may become a maritime version of Greater Eurasia, making it possible to complement this purely overland construct with a naval component.

\section{References}

Brzozowski, A., 2019. Arctic Nations Bet on 'Blue Economy' to Reconcile Climate, Development Goals. Euractiv, 24 January [online]. Available at: 
$<$ https://www.euractiv.com/section/arctic-agenda/news/arctic-nations-bet-onblue-economy-to-reconcile-climate-development-goals/> [Accessed 14 August 2020].

EC, 2020a. European Commission. Trade. Policy. China [online]. Available at $<$ https://ec.europa.eu/trade/policy/countries-and-regions/countries/china/> [Accessed 14 August 2020].

EC, 2020b. European Commission. Trade. Policy. Japan [online]. Available at $<$ https://ec.europa.eu/trade/policy/countries-and-regions/countries/japan/> [Accessed 14 August 2020].

EC, 2020c. European Commission. Trade. Policy. South Korea [online]. Available at $<$ https://ec.europa.eu/trade/policy/countries-and-regions/countries/southkorea/> [Accessed 14 August 2020].

Gudev, P.S., 2018. Severny Morskoy Put': natsionalnaya ili mezhdunarodnaya transportnaya arteriya? [The Northern Sea Route: National or International Transport Corridor?] Russiancouncil.ru, 13 September [online]. Available at: <https://russiancouncil.ru/analytics-and-comments/analytics/severnyymorskoy-put-natsionalnaya-ili-mezhdunarodnaya-transportnaya-arteriya/ $>$ [Accessed on 14 August 2020].

Gudev, P.S., 2018a. Arkticheskie ambitsii Podnebesnoī [Arctic Ambitions of the Celestial Empire]. Rossiya v global'noi politike, 16(5), 14 September [online]. Available at: <https://globalaffairs.ru/articles/arkticheskie-ambicziipodnebesnoj-2/> [Accessed on 14 August 2020].

Gudev, P.S., 2018b. Северный морской путь: национальная или международная транспортная артерия? RSMD, 13 September [online]. Available at: < https://russiancouncil.ru/analytics-and-comments/analytics/severnyy-morskoyput-natsionalnaya-ili-mezhdunarodnaya-transportnaya-arteriya/> [Accessed 14 August 2020].

Ó Tuathail, G., 1996. Critical Geopolitics: The Politics of Writing Global Space. London: Routledge.

RIA, 2020. Uchyony otsenil riski dlya infrastruktury Severa ot tayaniya vechnoi merzloty [A Scientist Assessed Risks for the Russian North Infrastructure Caused by the Thawing of Permafrost]. RIA Novosti, 07 July [online]. Available at $<$ https://ria.ru/20200707/1573984337.html $>$ [Accessed 14 August 2020].

Zoledziowski, A., 2020. Arctic Sea Ice Is Melting So Fast It Just Hit a Record Low. Vice.com, 28 July [online]. Available at: $<$ https://www.vice.com/en_in/article/ bv85z3/arctic-sea-ice-is-melting-so-fast-i-just-hit-a-record-low $>$ [Accessed 14 August 2020]. 